\author{
Ярослава Кальба, \\ кандидат психологічних наук, \\ дочент кафедри психології \\ Тернопільського національного \\ педагогічного університету \\ імені Володимира Гнатюка
}

\author{
Yaroslava Kalba, \\ PhD of Psychology, \\ Associate Professor of Department of \\ Psychology of Ternopil \\ Volodymyr Hnatiuk National \\ Pedagogical University
}

E-mail: yaroslavakalba@gmail.com

ORCID 0000-0003-0589-9126

\title{
ДО ПРОБЛЕМИ РОЗВИТКУ ДУШЕВНО-ДУХОВНИХ ПОТЕНЦЙ ЗРОСТАЮЧОЇ ОСОБИСТОСТІ (ВЧИНКОВИЙ ПІДХІД)
}

\begin{abstract}
Розглянуто пошук нових смислових орієнтирів людського буття. Наголошено на актуалізації проблеми пізнання категорій «дух», «душа», «духовне», «душевне». Досліджено проблему дефініцій означених категорій. Виявлено, щцо у філософському дискурсі смислові контури понять «духовність» $i$ «душевність» встановлені ще не достатньо; смислова розбіжність понять «духовність» $i$ «душевність» здійснюється переважсно на описовому, а не категоріально-ідентифікаційному рівні; спільним для них визначається їхня ідеальність. Проаналізовано смислові відмінності означених категорій. 3'ясовано, щзо поняття «душа» охоплює суто індивідуальне, невловимо-релятивне, позбавлене стійкої структури і визначеності, натомість «духу» належить усе те, що є надбанням людства, раціоналізованим досвідом поколінь у різних сферах життєдіяльності людей. Зроблено висновки, щуо «дух», як властива людині особливість, з'являється у неї тільки на рівні самосвідомості й активного впливу на власну дійсність, щуо дозволяє співвідносити поняття «дух» $з$ поняттям «суб'єктність». Особливе значення відведено формі вияву людиною ї̈ сутнісних сил. Визначено вчинок як умову й засіб сутнісного самоствердження, як ймовірний автентичний спосіб буття молодої людини,

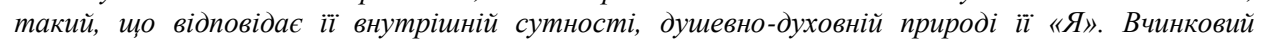
потенціал розглянуто на трьох рівнях людського буття відповідно до категорій загального, особливого та одиничного. Зроблено підсумки: на рівні загального вчинковість - ие можливість людини бути виключно людиною, а не якоюсь іншою істотою, принципова можливість учиняти, а не тільки діяти; на рівні особливого вчинковість - це конкретно-історична, специифічна вчинкова потенційність, зумовлена ситуацією життєдіяльності конкретного індивіда; на рівні одиничного вчинковість - ие індивідуальна можливість неповторного «авторського» вчинення. Доведено за дочүільне розглядати вчинковий підхід, як найбільш адекватний $і$ перспективний для розв'язання актуальних проблем виховання підростаючої особистості, зокрема у розвитку ї̈ душевно-духовних потенцій.
\end{abstract}

Ключові слова: вчинок, вчинковий підхід, вчинковий потенціал, вчинковість, душевне, духовне, духовність, душевно-духовні потенції, зростаюча особистість.

The search for new sense orientations of a human being are considered as a common feature of modern life. The actualization on a problems connected with categories «spirit», «soul», «spiritual», «physical» is underlined. The semantic difference between the concepts of «spiritual» and «psychical» is carried out mainly their descriptive rather than categorically-identifying level. Therefore, their commonality is determined by their ideality. We consider their semantic differences, in particular the concept of "soul» includes a purely individual, elusively-relational and devoid of a stable structure, whereas the "spirit» includes everything that is the property of humanity, all experience of generations in different spheres of human activity (philosophy, politics, morals, art, religion in the form of knowledge, assessments, norms, tastes, etc., and is objectified as truth, goodness, evil, beauty, ugliness, justice, freedom, patriotism, love, faith). We can assert that the «spirit», as a person's peculiarity, appears on level of self-consciousness and active influence on one's own reality. It means that the notion of «spirit» correlates with the notion of «subjectivity». The special meaning is given to the form 
of person's essential powers expression. The action is understood as a condition and a way of the essential person's self-affirmation. We can consider action potential on the three levels of human being according to the categories of general, special and individual. At the level of a general practice, it is the ability of a person to be solely a person, and not some other being, so to have the principle opportunity to make action. At the special historical level we mean specific action potentiality, conditioned by the situation of the life-story. At the level of the individual, we are talking about individual action, and, therefore the possibility of a unique «authorial» action. The active approach is considered to be the most adequate and perspective for solution actual problems of growing personality, in particular, in the development of his spiritual and psychical potentials.

Keywords: action, active approach, active potential, spiritual, psychical, spirituality, spiritual and psychical potencies, growing personality.

Постановка проблеми. Нове тисячоліття продукує новий тип людини, онтичний цикл, в якому складно розпізнати загальнолюдську ідентичність. Влада, достаток опановують світом, ув'язнюють духовний, душевний потенціал людства, тиражуючи задоволення, насильство, збагачення. Культ успіху стає фантомним ідеалом мас. Не вистачає сил, бажання, часу, а інколи й сміливості, аби призупинитись, втишитись, заглянути у власну душу, пізнати єство. «Духовне банкрутство» особливо відчутне, а відтак, по-особливому небезпечне серед підростаючого покоління. Затиснута лещатами внутрішніх та зовнішніх суперечностей, молодь бавиться у людське, видає уявне за дійсне. Одвічне гамлетівське: «...бути чи не бути?... бути собою, бути для себе, бути для інших?», перестає збуджувати життєдайну силу. Почасти життя молодої людини перетворюється на низку інтроектів, звичних дій, детермінованих ззовні. Визріває реальна небезпека «особистісного фіаско» - втрати себе, усього специфічно людського, що кристалізується в душі кожного і складає його цінність. Безсумнівно, пошук нових смислових орієнтирів людського буття - виразна ознака сьогодення, яка суголосить 3 проблемою пізнання категорій «дух», «душа», «духовне», «душевне».

Аналіз останніх досліджень та публікацій. Сучасна наука пропонує значну кількість наукових підходів до визначення та вивчення проблеми духовного розвитку особистості. Зокрема, феномен духовної культури досліджували Г. Балл, О. Даниленко, М. Данилов, Л. Смирнова тощо. Роботи М. Бахтіна, М. Боришевського, Г. Груць, З. Карпенко, О. Киричук, С. Помиткіна, М. Савчина, I. Степаненко, В. Роменця, В. Татенка, Т. Титаренко присвячені вивченню проблем духовності та формуванню духовних цінностей особистості. Духовний розвиток особистості розглядали у своїх працях А. Адлер, Р. Алперт, С. Грофт, I. Кант, О. Климишин, Р. Олексинко, О. Олексюк, Г. Райх, К. Роджерс, Е. Франкл, П. Юркевич тощо.

Духовна сфера особистості, моральні та ціннісні орієнтації, що є іiі складовою, підпорядковані розвитку. Вони не виникають спонтанно, в завершеному, сформованому вигляді, дозволяючи розрізняти добро і зло, красу й потворність, відвертість і фальш. Духовне збагачення дитини 


\section{Psychology}

відбувається поступово, а його динаміка та якість залежать від багатьох зовнішніх і внутрішніх чинників: від ціннісних орієнтацій, моральних настанов сім'ї, суспільства, в якому вона живе, запроваджених у цьому суспільстві традицій виховання тощо [Боришевський, 2010].

3 точки зору динамічної психології, першим критичним моментом у контексті означеної проблеми є дитинство - період, апріорі позбавлений щастя. Де факто, на кожній психотерапевтичній консультації спостерігаємо зондування пам'яті в пошуках почуття страху, сорому, провини. Холодна, зла мати, відсутній батько, заздрісливі брати й сестри - це демони, що фігурують у психологічній казці дитини. Такий сценарій прирікає сім'ю на психологію провини та відповідні взірці, моделі взаємин. Дж. Хіллман представник глибинної психології (психоархетипна школа) - зауважує, що реальні діти стають настільки нечутливими (збайдужілими), що вдовольняються псевдостимулами телебачення, i, коли настає підлітковий вік, їх треба «пристрелити», аби вони хоч що-небудь змогли відчути. Психоаналітик слушно зазначає, що учні сидять на уроках без мотивації, похмурі і злостиві блукають вулицями й у відчаї шукають чуттєвої трансцендентності в звуках, динаміці, сексі; вони шукають зміненого стану свідомості як альтернативного сценарію. На несвідомому рівні згадують дещо інше, інколи ціною самогубства [Hillman, 2006].

Другим проблемним моментом окресленого стану речей $\epsilon$ популяризація культу індивідуалізму, який, у свою чергу, ускладнює проблему ідентичності підростаючої особистості, ії самовизначення. На думку Е. Еріксона, криза ідентичності проявляється останнім часом у трьох основних сферах поведінки підлітків: проблема вибору кар'єри, членство в групі ровесників, вживання алкоголю й наркотиків. Перед сучасною молоддю постають два основні питання: «Хто я такий?» і «Як я впишусь у світ дорослих?». Демократична система породжує особливо серйозні проблеми, оскільки вимагає ідентичності, на кшталт, «зроби себе сам». 3 цієї причини зростаючу особистість фруструє питання: хто вона? I як їй знайти власну нішу в світі дорослих? У культурі з жорсткими соціальними нормами (зокрема, в країнах ісламу), де діють соціальні та статево рольові приписи, проблеми ідентичності мінімізуються й дотримання status quo $\epsilon$ обов'язковим [Хьелл, Зиглер, 2006: с. 243].

Третім проблемним моментом досліджуваної проблеми розглядаємо життєву дезорієнтацію юнаків, відчуття беззмістовності, спричинені руйнацією старих цінностей та дискредитацією нових, відсутністю культури рефлексії. Тому неасимільований досвід характеризується гіпертрофованим уявленням молоді про добро, справедливість, милосердя, способи реалізації цих цінностей. Підтвердженням $є$ виявлений у процесі емпіричного дослідження факт неспроможності учнів-старшокласників на зрілу диференційовану оцінку як своєї особистості, так і інших. Учням складно відповідати на запитання: «За якими основними критеріями Ти поділяєш людей на хороших та поганих?»; «За що, на Твою думку, Тебе 
поважають однокласники, а що в Тобі їм не подобається?». Типовими відповідями $\epsilon$ : «не знаю», «запитайте в них», що, в свою чергу, супроводжуються й зворотніми запитаннями: «А як це зрозуміти?»; «Поясніть, що це означає» [Кальба, 2011: с. 149].

На думку Е. Франкла, «екзистенційний вакуум», в якому молоді люди скаржаться на внутрішню порожнечу, страждають від відчуття беззмістовності і марнотратства, $\epsilon$ «чимось соціогенним, ... духовною бідою». Апатія і нудьга - головні ознаки екзистенційної фрустрації. Учений говорить про невротизацію людства, про «масову невротичну тріаду», описуючи три основні ефекти: депресію, наркоманію й агресію. Наслідком депресії $\epsilon$ рівень самогубств, який зростає особливо серед молоді. Пригнічуючи свою духовність, молода людина втрачає зв'язок зі своїми духовними центрами, найглибшими джерелами відчуття сенсу життя: «...як тільки ангел в людині подавляється (пригнічується), він перетворюється у демона» [Нельсон-Джоунс, 2000: с. 166].

Якими ж шляхами повинна йти сучасна психолого-педагогічна наука, аби іï вплив на розвиток, виховання дітей приносив відповідні результати?

Метою дослідження є аналіз актуальних орієнтирів виховного, соціалізуючого впливу сьогодення, визначення вчинкового підходу як найбільш перспективного у розвитку душевно-духовної активності зростаючої особистості.

Виклад основного матеріалу. Почасти говорять й аналізують людину, ii розумові здібності, рівень іiі інтелекту, емоційне життя, наскільки те й інше $\epsilon$ частиною іiї свідомого, публічного життя, забуваючи при цьому, що у неї набагато глибше коріння, що інтелект, яким вона так пишається, й емоції, які не завжди здатна контролювати, далеко не виявляють їі цілісність.

Вельми актуальною видається думка В. Татенка на те, що сучасна психологія не може обмежуватися лише дослідженням умовних чи безумовних рефлексів, вищих психічних функцій, темпераменту, характеру, свідомого та несвідомого у психіці. Вона повинна визнавати для себе проникнення у сутнісні глибини буття конкретної емпіричної людської істоти, у світ її значущих переживань, цінностей, смислів як діяча, автора і виконавця власних проектів життєздійснення, що «дозволяє сутнісно поглибити уявлення про позатілесну реальність як таку, що не тільки відображає чи регулює, але й творить дійсність» [Татенко, 2008: с. 3].

На часі розгляд буттєвого статусу сучасної молодої людини в контексті уявлень про «душу», «дух», «душевне», «духовне», пошук автентичної форми вияву сутнісних сил, їхнє потенціювання тощо.

Існує багато літературних та повсякденних варіацій понять «дух», «душа»: «великодушність-малодушність», «задушевна бесіда», «вдихнути душу», «люблю душевно», «душевний трепет», «спорідненість душ», 


\section{Psychology}

«душевна глибина», «сила духу», «духовна висота», «бойовий дух», «впасти духом», «злий дух» тощо.

Аналіз проблеми дефініцій виявляє, що у філософському дискурсі смислові контури понять «духовність» і «душевність» встановлені ще не достатньо, хоча важливі інтенції в цьому напрямку вже існують [Помиткін, 2007; Савчин, 2010].

Смислова розбіжність понять «духовність» $\mathrm{i}$ «душевність» здійснюється переважно на описовому, а не категоріальноідентифікаційному рівні. Одне видається дійсним: духовне не є просто продовженням чи вищим виявом душевного, досконалістю душевного. Не можна говорити, що десь закінчується душевне і починається духовне, існує певна сфера, де відбувається взаємне проникнення. Складність розпізнавання полягає в тому, що духовний досвід людиною усвідомлюється крізь призму душевного: всі духовні явища так чи інакше відображаються в нашій душі.

Термін «душа» - одне із найзагадковіших явищ, про суть і природу якого й досі ведуться суперечки між «світськими» та «релігійними» спільнотами. Виникнення цього поняття пов'язане 3 анімістичними поглядами первісних людей, які намагалися осмислити такі незрозумілі для них явища, як сон, втрата свідомості, смерть тощо. 3 найдавніших часів під «душею» розуміли якусь цілющу силу чи особливий орган, що нерозривно пов'язаний 3 тілом, або тимчасово перебуває у ньому. Душа або підкорюється тілу, або володарює над ним, вона або вічна, або смертна, або локалізована в тілі, або ж охоплює його цілком. У добу рефлекторної теорії Сеченова-Павлова, термін «душа» вживався як синонім терміну «психіка». Вважалося, що ця проблема може бути вирішена наукою, насамперед фізіологією та психологією, а у філософії - теорією відображення.

Термін «дух» до недавнього часу майже не згадувався у вітчизняній літературі, а якщо й вживався, то хіба в релігійному або містичному контекстах.

Філософсько-психологічна література пропонує власні дефініції понять «дух», «душа». Позаяк, спільним для них визначається їхня ідеальність. Проте, якщо розкривати їхні смислові відмінності, то поняття «душа» охоплює суто індивідуальне, невловимо-релятивне, позбавлене стійкої структури і визначеності, натомість «духу» належить усе те, що $\epsilon$ надбанням людства, раціоналізованим досвідом поколінь у різних сферах життєдіяльності людей, що фіксується у філософії, політиці, моралі, мистецтві, релігії в формі знань, оцінок, норм, настанов, смаків тощо і об'єктивується як істина, добро, зло, краса, потворність, справедливість, свобода, патріотизм, любов, віра, оптимізм тощо [Хамітов, 2002].

Таким чином, поняття «духовність» виступає як смисловий еквівалент категорії духу (С. Пролеєв), відображає сутність людського духу як специфічної форми іiі самовизначення у світі (Л. Буєва), 
розглядається як іманентна здатність людини до вільного діяння (О. Киричук, 3. Карпенко).

У такій предметній царині «душа» постає як винятково індивідуальний емоційний збудник, з властивими тільки їй схильностями та переживаннями, як «осередок, ядро усієї духовності» (Г. Горак). Отож, поняття «душевність» у такому контексті позначається як здатність, спроможність до конкретно вираженої любові, співчуття. Натомість поняття «бездушність» визначається як «суспільно нерозвинута чуттєвість» (В. Федотова), як своєрідний стан душевної хвороби, завершеною формою якої $\epsilon$ «моральний ідіотизм» (І. Ільїн). Отже, такі соціальні почуття, як, наприклад, любов до рідних, Батьківщини, співчуття до ближнього тощо індивідуалізуються, складаючи життєві сили «людської душі», їі дійсність.

Зазвичай, раціоналізація психічного життя людини наносить шкоду «душі», і нівелює задушевність у стосунках. Ще Г. Гегель зазначав, що людиною задушевною називається та, яка дає в усій силі проявитися своїй, хоча б обмеженій, але прониклій почуттям індивідуальності і яка цілком перейнята їі особливостями [Гегель, 1977: c. 246].

У свою чергу Е. Фромм визначав поняття «душевна сила» як мужність жити, здатність протистояти спробам піддати небезпеці «надію» $\mathrm{i}$ «віру», зруйнувати їх шляхом перетворення в голий оптимізм чи в «ірраціональну віру». Це здатність сказати «ні» тоді, коли весь світ хоче почути «так». На його думку, в цьому й полягає суть одного із визначень людини - як homo negans, тобто людини, яка може сказати «ні» заради своєї совісті, любові й правди [Фромм, 1999: с. 92].

Виявляється, існує думка навіть щодо позатілесних виявів статі (метаантропологічна позиція Н. Хамітова), у контексті якої «духовне начало» розглядається як екзистенційний вияв чоловічого - здатність до творчого поривання, радикальної самотрансценденції, до виходу за власні межі, а «душевне начало» - екзистенційний прояв жіночого - здатність до любові та співчуття [Хамітов, 2002].

Однак, якщо повернутися до земних реалій, традиційно людину розглядають як біосоціальну духовну істоту. Акцент у цьому контексті ставиться на одвічному протистоянні біологічних інстинктів та соціальних вимог, яке, власне, й сковує «дух» людини - те, що дає їй змогу чинити супротив і одному, й іншому. Яскравий приклад-підтвердження цьому знаходимо у християнстві: істинні християни не шукають виправдання своїм гріхам, що завжди є поступкою перед власними інстинктами, тиску ззовні, хибною сентенцією: «На все воля Божа». Адже воля в людині, Бог завжди залишає за людиною право вибору на користь добра чи зла. Цим християнство підносить людину до Царства Духу, яке вона спроможна обрати й вистраждати в собі.

Принагідно, звертаємося до теми страждання. Існують марні страждання, які нічого, крім фізичного дискомфорту, не створюють 


\section{Psychology}

(як наприклад, зубний біль). У той же час існують душевні страждання, що сприяють духовному зростанню, які $€$ шляхом до пізнання внутрішніх глибин, інших вимірів. У духовному житті єдиний шлях до відродження особистості, шлях до покаяння лежить через страждання. У стражданні відбувається народження людини, і це не апологетика страждань: ще Ф. Достоєвський закликав не шукати хреста, не прагнути до страждань як до мети, але й не втікати від них, якщо вони випали на долю.

Отож, з одного боку страждання - зло (як метод соціальної терапії), але 3 іншого - релігійний досвід людства вказує нам, що страждання бувають у кінцевому підсумку й благими, коли біль - це голос, яким говорить 3 людиною Бог: дуже часто по-іншому її не окликнути. Можливо, саме в цьому і $\epsilon$ зв'язок душевного та духовного: страждання душі гартують дух людини.

Вочевидь свобода морального вибору, совісті, вільне волевиявлення - найістотніша сутність людини. Знаходячи в собі совість, людина підноситься до щастя бути в істинній собі. 3 давніх давен «дух» у народі пов'язується не тільки з розумом, але й з волею, що підтверджує й прозаїчний вислів - «людині для злету потрібна сила духу, а не пір'я». А тому можемо твердити, що «дух», як властива людині особливість, 3'являється у неї тільки на рівні самосвідомості й активного впливу на власну дійсність, що дозволяє співвідносити поняття «дух» 3 поняттям «суб'єктність», з огляду на спільну для них сутнісну здатність до творення [Татенко, 2017]. На це вказує й теза «дух творить собі форми», яку можна вважати класичною інтерпретацією співвідношення між духовним станом людини та його ймовірними формами вияву.

Проте сфера тілесного - ймовірніший шлях розуміння духовного, аніж душевного, тобто тіло можна розглядати як необхідну форму існування людського духу. Якщо «дух» - це об'єктивно існуюче, надіндивідуальне начало, яке можна відстежити, дослідити, то душевне це те недоторкане, сакральне, яке непідвладне людському оку.

Окреслені категорії можна препарувати й далі, проте не варто піддаватись омані: ми не суто духовні істоти, ми не душа, ув'язнена в тілі чи на певний час пов'язана з ним, і цілісність людини - не в дусі чи іiі душі, а в духовно-душевному єднанні з тілом.

Логічним на цьому етапі постає запитання: чи існує своєрідна онтопсихосоціальна форма вияву душевного, духовного? У чому полягає ii специфічність, особливість? Йдеться про потенційну екзистенційну автономність, ймовірний автентичний спосіб буття молодої людини, такий, що відповідав би ії внутрішній сутності, душевно-духовній природі ії̈ «Я». Вважаємо, що такий спосіб цілком реально існує. Орієнтуючись на дослідження М. Бахтіна й В. Роменця, можемо стверджувати, що саме вчинок, на відміну від інших проявів активності (дія, діяльність), репрезентує людину цілісно, «монадно», гармонійно поєднуючи духовні, душевні, індивідуально-психологічні, унікально-неповторні інтенції та 
потенції ії «Я» [Кальба, 2011: c. 148]. Учинок цілком може бути віднесений до списку метаісторичних «феноменів вічності» (О. Бердяєв). Вчинкове закладене в людині на рівні архетипового. Людина приречена вчиняти, аби бути людиною. У цьому iі онтичний хрест i онтична перспектива [Татенко, 2008: с. 15].

Наведені твердження дають підстави розглядати вчинок як показник, умову душевно-духовного розвитку підростаючої особистості. Відтак, вчинковий потенціал доцільно розглядати на трьох рівнях людського буття відповідно до категорій загального, особливого та одиничного. На рівні загального вчинковість - це можливість людини бути виключно людиною, а не якоюсь іншою істотою, і звідси - принципова можливість учиняти, а не тільки діяти. На рівні особливого йдеться про вчинковість конкретно-історичну, a, отже, і про специфічну вчинкову потенційність, зумовлену ситуацією життєдіяльності конкретного індивіда. На рівні одиничного говоримо про вчинковість індивідуальну, а, отже, насамперед про можливість неповторного «авторського» вчинення [Кальба, 2011: с. 152].

Із зазначеного випливає, що зразки вчинкової активності можуть і повинні бути засвоєні новими поколіннями. Проте цього зовсім не достатньо аби молода людина була здатною продукувати власний вчинок як синтез душевно-духовного. Вчинковий потенціал як загальнолюдську сутнісну силу людина отримує в спадок, проте перетворити його на вчинковий потенціал «для себе» мусить вона сама, реалізовуючи тут свої суб'єктні сили й можливості. Трапляється, що таке вчинкове самопотенціювання здійснюється індивідом усупереч умовам життя. Проте це радше виняток, аніж правило. А тому доцільним видається шлях цілеспрямованого творення психолого-педагогічних умов, які б надали освітньому процесу вчинкового характеру, що $\epsilon$ цілком логічним i автентичним для власне людського способу передачі досвіду наступним поколінням. I тоді б психолого-педагогічна система зуміла за психічними функціями, структурами і механізмами побачити живу душу дитини 3 iї пориваннями і стражданнями, переживаннями проблем індивідуального буття і прагненням до високих духовних злетів [Татенко, 2017].

Примітною в цьому контексті видається й думка самих учнівстаршокласників. Результати емпіричного дослідження виявили, що юнаки позитивні вчинки розділяють на дві категорії, обравши за критерій розподілу «власну ініціативу», «власне бажання», «власне почуття», «поклик душі»:

a) «неживі вчинки» - «це те, що ми змушені робити в силу тих чи інших обставин, щоб люди погано не думали й не говорили про нас», це «вчинки на прохання», «вчинки за наказом», «вчинки-обов'язки», «вчинки за вимогою часу, традицій, менталітету» тощо; 


\section{Psychology}

б) «живі вчинки» - «це те, що йде 3 глибини, 3 тебе»; «коли душевний імпульс штовхає тебе на якусь справу», «це те, про що тобі шепоче твоя душа» [Кальба, 2011: c. 153].

Логічно, що вчинки, які підпадають під категорію «неживих», можна швидше розглядати як вияв формальної вихованості, культури зовнішньої поведінки «так треба» - це вимога часу, традицій, соціуму, страх покарання, безпечність, конформізм тощо. Це той спосіб існування, який властивий більшості. Натомість, пригадуючи слова Г. Сковороди «усе те сродне, що природне ...», вслід за класиком, визначаємо вчинки, означені учнями в іпостасі «живих», саме тією «справжньою» людською формою вияву нашого єства, зміст якої відповідає природі людини, і мова тут не лише про героїчні життєві моменти, а насамперед про прагнення бути вірним собі у дрібницях, у власному повсякденні, постійно, день за днем ...

Висновки. Результати проведеного дослідження вказують на існування кризового стану в соціумі. Це ті обставини, які змушують суспільство активно шукати протидію хибному становленню особистості молодої людини. Вкрай гостро постає проблема актуалізації внутрішніх життєвих рушіїв молоді, що включають уявлення про «душу», «дух», «душевне», «духовне». У цьому контексті особливе значення відводиться формі вияву людиною сутнісних сил. Розглядаючи вчинок як умову і засіб сутнісного самоствердження, вважаємо за доцільне розглядати вчинковий підхід як найбільш адекватний i перспективний для розв'язання актуальних проблем виховання підростаючої особистості, зокрема розвитку їі душевно-духовної сфери.

\section{ЛITЕРАТУРА}

Боришевський, 2010 - Боришевський М. Й. Дорога до себе : Від основ суб'єктності до вершин духовності : монографія. Київ : Академвидав, 2010. 416 с.

Гегель, 1977 - Гегель Г. Философия Духа. Энциклопедия философких наук : в 3 т. Москва : Мысль, 1977. Т. 3.471 с.

Кальба 2011 - Кальба Я. Є. Вчинковий потенціал особистості учня як предмет психологічного аналізу. Психологія і суспільство. 2011. № 2 (44). 190 с.

Нельсон-Джонс, 2000 - Нельсон-Джоунс Р. Теория и практика консультирования. СанктПетербург : Питер, 2000. 464 с.

Помиткін, 2007 - Помиткін Е. О. Психологія духовного розвитку особистості : монографія. Київ : Наш час, 2007. 280 c.

Савчин, 2001 - Савчин М. В. Духовний потенціал людини : монографія. Вид. 2-ге, переробл. і допов. Івано-Франківськ : Місто НВ, 2010. 508 с.

Татенко, 2017 - Татенко В. О. Методологія суб’єктно-вчинкового підходу : соціальнопсихологічний вимір : монографія. Київ : Міленіум, 2017. 184 с.

Татенко, 2008 - Татенко В. О. Сучасна психологія про душу, дух і, звичайно, про психіку. Соиіальна психологія. 2008. № 4. 190 c.

Фромм, 1999 - Фромм Э. Революция надежды. Санкт-Петербург : Ювента, 1999. 245 с.

Хамітов, 2002 - Хамітов Н. В. Духовність. Філософський енциклопедичний словник. Довідкове видання. Київ : Абрис, 2001. 254 с.

Хьелл, Зиглер, 2006 - Хьелл Л., Зиглер Д. Теории личности. 3-е изд. Санкт-Петербург : Питер, 2006. $464 \mathrm{c}$.

Hillman, 2006 - Hillman James. City and Soul. Uniform Edition. Spring Publications. 2006. Vol. 2. $416 \mathrm{p}$. 
Hillman, 2004 - Hillman James. Archetypal Psychology. Uniform Edition. Spring Publications. 2004. Vol. 1. P. 14-24.

\section{REFERENCES}

Boryshevskyi, 2010 - Boryshevskyi M. Y. Doroha do sebe : Vid osnov subiektnosti do vershyn dukhovnosti : monohrafiia. Kyiv : Akademvydav, 2010. $416 \mathrm{~s}$.

Hehel, 1977 - Hehel H. Fylosofyia Dukha. Entsyklopedyia fylosofkykh nauk : v 3 t. Moskva : Mysl, 1977. T. 3. $471 \mathrm{~s}$.

Kalba 2011 - Kalba Ya. Ye. Vchynkovyi potentsial osobystosti uchnia yak predmet psykholohichnoho analizu. Psykholohiia i suspilstvo. 2011. № 2 (44). $190 \mathrm{~s}$.

Nelson-Dzhons, 2000 - Nelson-Dzhouns R. Teoryia y praktyka konsultyrovanyia. Sankt-Peterburh : Pyter, 2000. $464 \mathrm{~s}$.

Pomytkin, 2007 - Pomytkin E. O. Psykholohiia dukhovnoho rozvytku osobystosti : monohrafiia. Kyiv : Nash chas, 2007. $280 \mathrm{~s}$.

Savchyn, 2001 - Savchyn M. V. Dukhovnyi potentsial liudyny : monohrafiia. Vyd. 2-he, pererobl. i dopov. Ivano-Frankivsk : Misto NV, 2010. $508 \mathrm{~s}$.

Tatenko, 2017 - Tatenko V. O. Metodolohiia subiektno-vchynkovoho pidkhodu : sotsialnopsykholohichnyi vymir : monohrafiia. Kyiv : Milenium, 2017. 184 s.

Tatenko, 2008 - Tatenko V. O. Suchasna psykholohiia pro dushu, dukh i, zvychaino, pro psykhiku. Sotsialna psykholohiia. 2008. № $4.190 \mathrm{~s}$.

Fromm, 1999 - Fromm E. Revoliutsyia nadezhdy. Sankt-Peterburh : Yuventa, 1999. $245 \mathrm{~s}$.

Khamitov, 2002 - Khamitov N. V. Dukhovnist. Filosofskyi entsyklopedychnyi slovnyk. Dovidkove vydannia. Kyiv: Abrys, 2001. $254 \mathrm{~s}$.

Khell, Zyhler, 2006 - Khell L., Zyhler D. Teoryy lychnosty. 3-e yzd. Sankt-Peterburh : Pyter, 2006. $464 \mathrm{~s}$.

УДК 159.922.1+37.015.3

DOI 10.31470/2308-5126-2019-42-1-77-90

Оксана Кікінежді,

доктор психологічних наук, професор, завідувач кафедри психологіі

Тернопільського національного педагогічного університету імені Володимира Гнатюка, провідний науковий співробітник, директорка науково-дослідного Центру з проблем гендерної освіти та виховання учнівської і студентської молоді НАПН

Украӥни - ТНПУ ім. В. Гнатюка
Oksana Kikinezhdi, Doctor of Psychology, Professor, Head of Department of Psychology of Ternopil Volodymyr Hnatiuk National Pedagogical University, the Director of the Scientific Research Centre of the Problems of Gender Education and Upbringing Pupils and Students of NAPS of Ukraine - Ternopil Volodymyr Hnatiuk National Pedagogical University

E-mail: okiki77777@gmail.com ORCID 0000-0002-9240-279X

\section{СТАНОВЛЕННЯ Я-КОНЦЕПЦЇ̈ ЖІНКИ / ЧОЛОВІКА В ЮНАЦЬКОМУ ВІЩІ}

У статті представлено емпіричне дослідження розвитку гендерної ідентичності в юнацькому віці. У контексті гуманістичної, генетичної та когнітивної психологї̈ та згідно 3 авторською моделлю статеворольової ідентифікації особистості розглянуто становлення персоніфікованого образу Я як маскулінно-фемінно-андрогінного конструкту. 3'ясовано, що специфіка розвитку тендерної ідентичності дівчат та юнаків 15-17-річного віку полягає в 